\title{
Most Relevant Enablers And Constraints Influencing The Spread of Telework in Portugal
}

\author{
Flávio Nunes ${ }^{1}$
}

\begin{abstract}
This paper reports the empirical findings of several surveys conducted among enterprises in Portugal in order to identify and summarize relevant enablers and constraints that may influence the implementation of telework in the Portuguese business environment. It is also provided some common characteristics that will help us draw the profile of the Portuguese potential teleworker.
\end{abstract}

\section{Introduction}

The use of telecommunications to partially or completely replace daily commuting to and from work is predicted to have a great impact on various fields of society, both directly and indirectly, and for that reason it has been a subject of an intense technical and public debate for a few years now. However, the high expectations, ranging from the decrease of commuting costs to timesaving or the diversification of employment in peripheral and rural areas, have not yet been met. The slow adoption of teleworking practices, among industrialized countries, calls for empirical studies with careful analyses of all elements that may influence its implementation, which would allow some international comparability in order to respond to the information needs of policy makers.

Although a large-scale implementation of telework has not yet occurred in Portugal, in this paper we will point out and analyse some visible tendencies in order to understand the effective role of telework during the past few years in a few different issues:

- as a factor contributing to the exclusion of groups without technical skills or financial resources to access the informational technologies, as well as those living in the Portuguese remote rural areas bypassed by the most relevant 'infostructures' (optical cables, wireless web access, DSL technology...);

- as a new opportunity for the integration of neglected Portuguese groups, specifically people with disabilities, because of their understandable difficulty to combine labour market participation with the temporal and spatial constraints of traditional office work;

- as an instrument with clear implications for house planning and land-use policy, as well as for the implementation of transport policies related to the commuting journeys that have been replaced, and the alternative forms of travel that have arisen in the context of telework;

- or as a way to improve the productivity of existing businesses, in order to enable them to compete more effectively on world markets.

It is widely acknowledged that the promotion of telework cannot be based merely on the high level of awareness, if concrete results are to be achieved; systematic actions are needed and must be improved to create adequate attitudes and technical facilities in public and private organizations, as well as facilitate their decision-making processes concerning teleworking experiments. For this reason, to better understand and evaluate these tendencies related to the dissemination of telework during the past few years, it is important to analyse the evolution of

\footnotetext{
${ }^{1}$ Lecturer in the Department of Geography - University of Minho, Campus de Azurém, 4800-058 Guimarães, Portugal (flavionunes@geografia.uminho.pt)
} 
the Portuguese government's policies and legislation in this field. What are the main political objectives? What instruments have been created to help the appearance of teleworking programmes on Portuguese companies, and with what results?

Although Portugal has been somewhat slow in formally adopting telework practices, one of the main results of this paper suggests a high number of potential teleworkers in Portugal. During a research that we have conducted on the APDT (the main Portuguese Association for the Development of Telework), almost one thousand information demands to this institution (between 1998 to 2002) were investigated. This paper summarizes the results and findings of this empirical work, giving us the opportunity to better understand the profile of the Portuguese potential teleworkers, in terms of age, gender, qualification and residence patterns, as well as a better knowledge of the most important difficulties faced by those people who see telework as a way of increasing their quality of life, but cannot yet participate in this new form of work organization.

\section{Telework as a currently changing concept}

There are several terms and definitions used to describe a flexible working alternative that involves work done away from the traditional office locations, through the use of telecommunications and networking tools. Telework, telecommuting, electronic homeworking, virtual officing, ework are a few examples of an enormous range of terminology that in some cases is restricted to a particular form of remote work (homeworking for instance), and in other circumstances has the advantage of avoiding over-specificity and can be applied to any kind of work involving the uses of telecommunications technologies to receive or send the work to a remote employer or business client.

It is widely known that the debate on this subject began in the early 70's, in the University of Southern California, when Jack Nilles presented the term telecommuting, during a research project for the National Science Foundation, which meant simply the opportunity to work from home using telecommunication links. At the time of the oil crisis, a special demand of new ways to conserving energy was identified, and it is with this background that the author discusses the potential in the substitution of commuting by the technically possible telecommuting. This concept would be materialized as an electronic mediated distance working, with advantages not only in energy-savings, but also in providing less traffic and environmental pollution, less stressful working conditions, more time for family and leisure or the possibility of substantial savings in office costs.

In the following studies Jack Nilles distinguishes telework from telecommuting. In his view, telework can be defined as the use of computers and telecommunication technologies as a primary communication tool in the workplace, which can be conducted from a centralized or a decentralized location, while telecommuting implies decentralization, "in effective telecommuting, if the information worker commutes at all, it is to the corporate office nearest his or her home" (Nilles, 1985, p. 202). Thus, telework is simply the use of telecommunications technology to conduct work, like for instance teleconferencing, facsimile transmission, e-mails or cellular phone calls, which does not necessarily involve remote work. In Nilles' view, telecommuting is both telework and remote work, which implies the use of telecommunication as a tool to allow for the worker to be physically distant from the primary worksite (the location of the supervisor).

However, in some other approaches based solely on the etymology of the word telecommuting, a form of work is considered as telecommuting if it involves remote supervision and if the commute trip is reduced or eliminated. Under these criteria (distance and commuting), it was argued that telecommuting does not require computers or telecommunications on every 
occasion. This perspective is the one shared by the European Foundation for the Improvement of Living and Working Conditions, which presented in 1986 a definition accordingly to the following three prerequisites. Firstly, the place where the work is carried out is spatially independent of the location of the employer or client; secondly the work is done predominantly with electronic terminals; and finally a telecommunication link is used between the teleworker and employer or client, but it was made clear that in some cases the work results are stored on data carriers and later transmitted to the employer or client. A few years later, the definition of the US South Quality Management District (AQMD), presented in 1990, did not yet exclude the possibility of store work results being transmitted later by post, courier service or other means, and in this sense "telecommuting is working at home or at an alternate location and communicating with the usual place of work using electronic or other means, instead of physically travelling to a more distant work site" (Mokhtarian, 1991).

Even so, in the beginning of the 90's the term acquired a meaning that goes a bit beyond simply working at a distance. With the substantial improvements of electronic equipments and telecommunication infrastructures, the concept is definitively linked to the use of information and communication technologies (ICTs) to enable people to work away from their employers (Huws, 1991; Weijers, Meijer and Spoelman, 1992; Oborne, 1992). Since then, the definition of teleworking excludes the 'outworkers' (understood as traditional home workers making no use of telecommunications as part of their work), which means that work supervision must be carried out and work results have to be presented at least partially through telecommunication. Gray, Hodson and Gordon (1993) decided to add another trait to this concept, arguing that this flexible way of working must be the chosen method in a significant proportion of work time (they suggest two days a week, just for reference), in order to exclude people who work remotely only on very few occasions.

At that time, in several analyses made to predict the future of work, a multitude of terms came into existence to describe decentralised forms of work in which workers are employing modern telematic equipment: 'electronic homeworking', 'remote working', 'networking', 'flexible working', 'flexiplace', 'flexiwork', 'electronic cottage', and so on. As a result of this situation, different people use these words with slightly different meanings, or even a variety of other words with similar connotations.

Defining teleworking remains an uneasy task because it covers a great variety of working practices that in some cases have little similarity to one another. Thus, the challenge faced by many analysts was to define and present different types of teleworking, and as a result of this work, the most common typology systematizes three different organisational forms of telework, defined in terms of the types of work relationships available: homeworking, group-based teleworking and flexible teleworking (or flexiwork). However, like any other kind of typology, it is understandable that some teleworking practices can be included in more than one of the groups described below.

- Homeworking is the classical form of telecommuting which provides employment possibilities for workers with restricted mobility or for those who prefer to work at home using telematic systems to communicate with the central organisation.

- Group-based teleworking, or working from a telecentre closer to home than the primary office, includes at least three different types of "telecommuting centers". The satellite office is a decentralised office that belongs to a single company, provided with all the essential technical equipment and located within easy reach of the workers' homes. The neighbourhood offices belong to various companies with employees from the same municipal district, set up to reduce the time and expense of the commute to and from the main office facility, with the advantage of involving less expensive spaces in comparison to a central location. The electronic service offices are provided by independent firms offering a wide range of information technologies or specialised services to all kinds of 
business, for whom it would be too expensive to acquire their own location and computer system.

- With networking or flexible teleworking systems, the workers can determine alternative locations to carry out certain tasks and usually their presence in the company is limited to a few meetings; also, they are paid according to the workload. There are numerous examples of flexible work arrangements in professional occupations, like advertising professionals, writers, graphic designers, translators, data entry or word processing professionals (or others information workers, some of them self-employed). Some authors, like Gray, Hodson and Gordon (1993) or Benhamou et al. (1994), prefer to distinguish the nomadic or mobile telework as a new flexible way of working, which is growing as the technology becomes available at appropriate prices, allowing people to become constant travellers, being at the same time closely in touch with central resources and also with their families (the work is carried out in connection with travels and hotel stays).

Despite these efforts to achieve systematisation, the confusion between telework and telecommute persist. The concept of telework, despite being very different from the notion proposed in the middle 80 's by Nilles, is still a very broad one, although it is possible to say that it is linked to the use of ICTs to practice remote working of some kind (Muhlbacher, J., 1998, Qvortrup, 1998). In a strict sense, 'telecommuting' is a part of the broader concept of 'teleworking,' "to begin it implies that certain trips to work, for example a few days a week, are substituted with work from home, from a satellite centre or from a neighbourhood office aided by data and telecom, moreover, it exclusively applies to employees, not self-employed persons" (Forseback, 1995, p. 7).

In 2000, with the establishment of the EMERGENCE project, ework was defined as a term referring "generically to any type of work which involves the digital processing of information and which uses telecommunications link for receipt or delivery of the work to a remote employer or business client" (Huws, 2001, p. 2). Nowadays, this is the term favoured by the European Commission. Although it does not refer to distance (as does the prefix 'tele'), it still has the advantage of avoiding confusions with telecommuting (which is constantly happening with telework) and not being too specific, as it is not restricted to a particular form of remote work, such as homeworking, telecommuting or mobile working.

With the ambitious goal of measuring and mapping the location of ework throughout Europe, the EMERGENCE approach presented a new conceptual framework "within which all forms of ework so far identified by researches can be grouped" (Huws and 0'Regan, 2001, p. 5). This typology classifies nine different categories of ework, based on two broad distinctions: a legal/contractual distinction and the type of workplace (Table 1). On the one hand, a legal distinction can be made between work carried out internally, normally with a contract of employment, and the outsourced supply of services. On the other hand, there is the distinction between work in isolation (working from home or nomadically), and work carried out by groups of workers in shared premises away from the central office.

Table 1. A typology of ework categories

\begin{tabular}{|c|c|c|}
\hline & Internal employees & Outsourced services \\
\hline $\begin{array}{l}\text { Individualised workplace/away from } \\
\text { 'office' premises }\end{array}$ & $\begin{array}{l}\text { - } \quad \text { employed telehomeworkers } \\
\text { - } \quad \text { mobile employees }\end{array}$ & $\begin{array}{l}\text { - freelance teleworkers } \\
\text { or mobile workers }\end{array}$ \\
\hline $\begin{array}{l}\text { Workplace based on shared 'office' } \\
\text { premises }\end{array}$ & 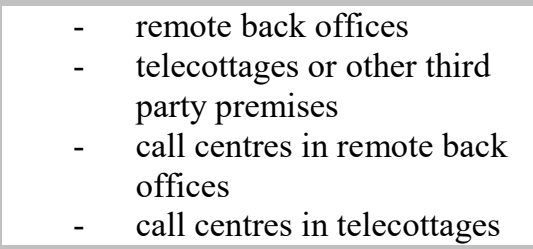 & $\begin{array}{ll}- & \text { specialist business } \\
\text { service supply } \\
\text { companies } \\
\text { - } & \text { outsourced call centres }\end{array}$ \\
\hline
\end{tabular}


It is obvious that as a result of the nature of telework itself (or ework), being a concept with very vague boundaries, it is extremely difficult to define and measure it (Sullivan, 2003). It is likely that definitions, policies, and guidelines will continue to be refined as additional empirical experience will be progressively acquired, also as a result of more fundamental structural changes in the 'nature' of work relations and organisational forms, specially as regards the spatial organization of work (Hardill and Green, 2003). We are not dealing here with the workplace as the traditional fixed geographical space, but as a set of networks and relationships. In other words, the workplace today can be found anywhere electronic networking is possible (planes, trains, hotel rooms, airport lounges...).

\section{Portuguese dissemination of telework: a synthesis of empirical findings}

In this part we will focus on the main empirical findings of several surveys conducted among enterprises in Portugal (Table 2), while trying to systematize them. This comparative analysis was very helpful in identifying and summarizing relevant enablers and constraints that may be influencing the implementation of telework in the Portuguese business environment. Before moving on to the main issues, it is important to say that the process of telework diffusion in Portugal has been primarily explored in the context of several individual academic dissertations, despite the interest shown by a few collective research projects, which have been awarded significant contributions from public funds.

Although the large-scale implementation of telework has not yet occurred in Portugal, the research objectives are mostly concerned with the further implications to business and rearrangements of work processes, with a comparative lack of interest in terms of the perceived social advantages and disadvantages to Portuguese citizens as individuals and as employees.

Table 2. The main objectives and methodological approach of several collective research projects and academic dissertations, whose purpose was to understand the diffusion process of telework in Portugal and its further implications.

\begin{tabular}{|c|c|}
\hline OBJECTIVES & METHODOLOGY \\
\hline $\begin{array}{l}\text { Araújo, E. (1998): academic dissertation. } \\
\text { Purpose: evaluating the Portuguese situation in terms of } \\
\text { the social effects of telework, the relevant factors to } \\
\text { telework implementation, and the potential teleworkers' } \\
\text { perception of these work practices. }\end{array}$ & $\begin{array}{l}\text { Two case-studies and interviews/inquiries to } 52 \\
\text { workers from six service companies. }\end{array}$ \\
\hline $\begin{array}{l}\text { Fiolhais, R. (1998): academic dissertation. } \\
\text { Purpose: providing a framework of the impact of } \\
\text { adopting formal telework practices in the Portuguese } \\
\text { scenario. }\end{array}$ & $\begin{array}{l}\text { Eight extended interviews with teleworkers, all from } \\
\text { the same firm (Hewlett-Packard Portugal), probably } \\
\text { the first firm in Portugal to undertake an explicit } \\
\text { practice of telework. }\end{array}$ \\
\hline $\begin{array}{l}\text { Silva, A. et al. (1998): research project with a contract, } \\
\text { known as the most thorough and exhaustive study } \\
\text { carried out in Portugal, supported by European funds. } \\
\text { Purpose: describing the diffusion process of telework in } \\
\text { Portugal and its future tendencies, as well as to define a } \\
\text { pro-active strategy to promote these new work practices. }\end{array}$ & $\begin{array}{l}\text { Combination of a quantitative and a qualitative } \\
\text { approach: } 637 \text { answers to an inquiry sent to a total of } \\
3500 \text { firms, five detailed case-studies in enterprises } \\
\text { implementing telework practices, } 35 \text { interviews with } \\
\text { Portuguese agents relevant for the development of } \\
\text { telework (government agencies, local authorities, } \\
\text { trade unions, economic associations...), a focus- } \\
\text { group with } 13 \text { national employment specialists and } \\
\text { ICTs experts, and also a webpage where any } \\
\text { interested person was allowed to give his/her opinion } \\
\text { about the research subject. }\end{array}$ \\
\hline (1998): academic dissertatiol & quiry sent by email to a total \\
\hline
\end{tabular}




\begin{tabular}{|c|c|}
\hline $\begin{array}{l}\text { Purpose: determining the main implications of telework } \\
\text { in the management of Portuguese service companies. }\end{array}$ & 700 firms. \\
\hline $\begin{array}{l}\text { Correia, A. (1999): academic dissertation. } \\
\text { Purpose: evaluating the implications of telework for } \\
\text { management models and in terms of the workers' } \\
\text { expectations. }\end{array}$ & $\begin{array}{l}\text { A case study of a pilot project on homeworking } \\
\text { developed in the biggest telecommunications } \\
\text { company in Portugal (Portugal Telecom). }\end{array}$ \\
\hline $\begin{array}{l}\text { Gomes and Aouad (1999): related to an academic } \\
\text { dissertation. } \\
\text { Purpose: identifying the changes caused by telework in } \\
\text { the Lisbon Metropolitan Area housing stock (typology, } \\
\text { dimension...). }\end{array}$ & Interviews, questionnaires and case studies. \\
\hline $\begin{array}{l}\text { Sousa, M. (1999): academic dissertation. } \\
\text { Purpose: identifying the main factors that are obstructing } \\
\text { the diffusion of telework in Portugal. }\end{array}$ & $\begin{array}{l}39 \text { answers to a mail inquiry sent to a total of } 170 \\
\text { information-processing firms. }\end{array}$ \\
\hline $\begin{array}{l}\text { Brandão, M. (2001): related to the PORCIDE research } \\
\text { contract project. } \\
\text { Purpose: studying the use of telework to develop the } \\
\text { capabilities of physically handicapped people, helping } \\
\text { them promote their services and achieve full } \\
\text { professional integration. }\end{array}$ & $\begin{array}{l}\text { A consortium of several companies, each them } \\
\text { providing different contributions to the project: } \\
\text { project leadership and technical know-how; } \\
\text { telecommunications infrastructures, internet } \\
\text { communications, marketing/advertising, hardware } \\
\text { and software. In a subsequent phase, the selected } \\
\text { individuals were provided with the necessary } \\
\text { equipments and training, as well as on-going support, } \\
\text { focused on technical matters and social integration } \\
\text { issues. }\end{array}$ \\
\hline
\end{tabular}

Santana and Rocha (2001): research contract project, 97 answers to an inquiry sent to a total of 550 firms. conducted thanks to funds from the AveiroDigital IST action plan (Social Integration by Telework).

Purpose: determining the availability of firms located in the Aveiro District to adopt new working methods provided by telework, and to discover the managers' opinion about the activities that could be implemented by telework, particularly by employees with special needs.

\begin{tabular}{l|l}
$\begin{array}{l}\text { Roldão, A. (2002): academic dissertation. } \\
\text { Purpose: evaluating the reduction of commuting trips by } \\
\text { teleworking practices in the Lisbon Metropolitan Area, } \\
\text { as well as determining what kind of influence it has on } \\
\text { actual decisions about housing locations. }\end{array}$ & $\begin{array}{l}\text { A spatial statistical analysis of official inquiries } \\
\text { theoretical models about the use of urban soil, } \\
\text { introducing telework as an influential factor for } \\
\text { housing location choices. }\end{array}$ \\
$\begin{array}{l}\text { Casaca, S. (2003): related to an academic dissertation. } \\
\text { Purpose: studying the flexible ways of working in the } \\
\text { information society, with a specific focus on telework. }\end{array}$ & $\begin{array}{l}\text { Several in-depth interviews (personal background) to } \\
\text { teleworkers, complemented with visits to their } \\
\text { homes/workplaces in some cases. }\end{array}$ \\
\hline
\end{tabular}

Comparing all these studies, it is safe to say that, in Portugal, telework is a very embryonic working practice. From all the telework modalities, in Portugal the most representative ones are informal and occasional telework from home (mainly involving computer experts) and mobile telework. Nevertheless, there are a few cases of formal and structured implementation of telework programmes in Portuguese firms.

\section{Infrastructure}

There are no significant technological limitations for the diffusion of telework in Portugal. However, there are still a few important barriers as regards ICT literacy in rural areas, high telecommunication costs, safety proceedings on the information transmission process, and in terms of problems of investment for some of the firms that are constantly upgrading their ICTs.

\section{Existing/prospective employer views}

According to business managers, telework is perceived more as a way to reduce costs than a way to improve productivity and quality (a drawback that results from the reduction of teamwork benefits). This assumption arises from the fact that telework is seen in general as a way to spin-off some back-office tasks, in order to reduce operating costs by establishing contracts for the external provision of services. This tendency to outsource activities could be responsible for 
the future use of telework as a way to weaken work contracts, which would probably turn it into something negative.

According to what Portuguese business managers believe, the functions that are more adequate for telework are those related with computer expert activities, or others, less qualified, such as word processing and data collection, which reveals an erroneous interpretation of the concept of telework. However, the results obtained in a few more recent questionnaires seem to suggest that, nowadays, among the more popular functions in telework are those that companies find difficult to include in their structures. Some managers revealed that telework is a good working method, allowing for flexible access to qualified services, which would certainly be more expensive if working as internal activities.

Despite these constraints, and as many international studies point out, in Portugal, such as in many other countries (Bertin and Denbigh, 1998), management attitudes, particularly resistance to the change, is the main obstacle to the diffusion of telework, especially because of the expected difficulties in terms of control and supervision of the workers' performance.

The prevalence of the traditional models for human resources management encourages scepticism between Portuguese employers, and this disbelief is reinforced by the lack of information and training on the viability of telework. Despite this general tendency, the service firms that have already developed telework programmes made a positive evaluation of those experiments, emphasizing the advantages related to the possibility of integrating employees with special needs in working schedules and with the reduction of operating costs.

\section{Existing/prospective teleworker views}

A suspicious and reticent attitude towards telework is a common characteristic not only among managers but also among those employees who work in companies who are likely to implement telework activities, especially as a result of a lack of social and juridical protection, and also because of an unwelcome decrease in surveillance and supervision (the transition from traditional physical work relationships to a more distant control will not be an easy process in Portugal). Among employees there is the assumption that telework will probably lead to a more distant attitude from the employers.

The results obtained through some studies carried out with Portuguese teleworkers allow us to question the additional flexibility that results from the opportunity to work at more convenient times. The workers' most common explanation for preferring telework is the desire for autonomy, but nevertheless in several cases the ability to control time is very small, in consequence of the need to work according to specific results or goals, to meet quality demands and deadlines, or because it is hard to balance work and family life. Some examples show us that despite not having to waste time with commuting, the workers have not increased their leisure periods, have not been more involved in the local community and do not necessarily have a better family life (children and partners may find irregular working hours in the evening and weekends difficult to cope with).

The traditional perception of work-time and work-space (defining characteristics of an acquired social "status") are seen, by Portuguese potential teleworkers, as influential and decisive factors to avoid fulltime telework. These workers avoid to some extent mixing work with their intimate and familiar space, nor do they accept losing the social life provided by the traditional work environment (fear of isolation).

\section{Jobs for staff with disabilities}

As regards the benefits of telework in terms of integrating citizens with special needs, practical experiences carried out in Portugal since 1997 using telework to achieve the professional integration of handicapped people (the PORCIDE project involves around 80 handicapped people) have shown that it is not just a charitable investment, it is also a viable business, with 
benefits to employers who believe in these new working methods to outsource computer related activities. It also brings advantages concerning the promotion of the workers' first steps towards autonomy and competitiveness in a context of personal development. However, the results seem to suggest that without good team spirit it would be impossible to reach the defined goals, and that not all the workers involved showed suitability for this method of work.

\section{Implications for urban planning strategies}

Concerning telework implications for housing planning and land-use policy in Portugal, and especially in some studies conducted in Lisbon Metropolitan Area, the impact of telework is not significant, particularly in regard to the reduction of commuting trips to those who work in a different municipality, or to new options and decisions concerning housing locations. On the other hand, the homes of Portuguese workers, in general, are not big enough to accommodate an office suitable for work (the houses' space requirements are hard to meet in the Portuguese context). And, if a teleworker requires some public and social services close to his/her workplace, the peripheral Portuguese cities won't be able to provide such privileges, as they were planned for an overnight population.

\section{State involvement in telework promotion}

Finally, the most consensual conclusion from all these analyses has to do with the fact of the Portuguese government clearly not having a pro-active programme for the increase of telework practices in Portugal, for instance by promoting a network of telecenters throughout the country, or by encouraging a consistent and coherent action plan to spread information and training about telework practices (the general lack of knowledge about telework concerns not only employers but also employees). However, the most expected contribution from the government, one which was mentioned in almost all these researches, has to do with the promotion of important adjustments to the labour legislation, in order to give social and legal protection to workers and to facilitate the establishment of telework programmes. The analysis of the already promoted formal telework practices in Portugal reveal the existence of several unusual problems that call into question the legitimacy of the current Portuguese labour legislation.

\section{The progress of Portuguese Government policies and legislation concerning telework}

The green paper launched in 1997 to promote the information society in Portugal clearly demonstrated that the Portuguese government had to develop a legal framework in order to delimit telework practices and facilitate its dissemination (MCT, 1997). According to the indications expressed in this strategic document, the public administration should subsidise the first steps (supporting telework pilot-projects) in order to demonstrate the importance of telework, not only as an instrument for a more balanced regional development policy but also as a contribution to better living standards in the metropolitan areas.

However, these recommendations were not included in the set of governance priorities that formed the basis of the Operation Programme for the Information Society (MCT, 2000), despite some isolated and sporadic actions promoted in the context of a few Digital Cities projects. These recommendations began to be integrated in the Portuguese governance priorities only with the current XV Portuguese Constitutional Government (which was sworn in during 2002). The new Portuguese Labour Act (promoted by the Ministry for Social Security and Work and approved in August of 2003, Law n ${ }^{\circ}$ 99/2003) includes a specific section related to telework (Table 3). 
Table 3. Portuguese Labour Act - special rules related to Telework

The telework contract must be written and should include: the tasks to be performed by the worker during and after the telework phase; the initial duration of the telework experiment; who owns the equipment and pays for maintenance and communication costs, as well as a reference to the companies' representative that will follow the worker's performance.

The contract is valid for a maximum of three years, and after this period (or in the first month, in case of bad adaptation) the worker has the right to return to his/her initial position in the company.

The worker may have a flexible working schedule, but the employer must respect the worker's privacy and his/her family rest periods (if the employee works from home, the supervisors' inspections are admissible between 9.00 and 19.00 only).

The jobs must comply with the maximum working hours (daily and weekly period) as any other worker.

The employer must install the technical equipment and bear the telecommunication costs, and the use of these equipments is restricted to the employer's needs, excluding the reception of information from trade unions.

The teleworker should receive technical training on ICTs, and may regularly contact other colleagues in order to avoid feelings of isolation.

Source: Portuguese Government (2003). Law nº 99/2003, DR 197 S.I-A, 2003-08-27

Correia (2003) draws our attention to the main dilemma of this new law, which has to do with the fact that the teleworker must be connected (on-line) to the employer during the normal working hours. This rule implies a rigid and inflexible schedule, which is contrary to the desired temporal and spatial autonomy. As a consequence of this legal framework, there is an expected risk of the employers' persistence in outsourcing options, which can be seen as the establishment of service providers' agreements in order to dissimulate telework situations.

Apart from this legal update, in June 2003 the Action Plan for the Information Society was presented (UMIC, 2003), revealing the priorities of the new government for the information society development. Among these political goals, telework stands out as a factor of competitiveness, and it was declared that in order to encourage the basic conditions to its diffusion and adhesion the State should contemplate several efforts, namely in three kinds of actions:

- promoting informative actions, in a joint work with business associations, to explain the advantages of telework and their organizational impacts;

- promoting training actions to teleworkers and potential teleworkers;

- establishing a network of local telecenters throughout Portugal.

As expected, the direct consequences of this new political goal are not yet visible. However, and as a result of some dynamism shown sporadically by public local authorities, there are some developments with practical results. For instance, the group of teleworkers registered in the Guarda telecenter have been providing services mainly related to translation $(60 \%)$, word processing (20\%) and web design (20\%). Furthermore, other telecenters have been emerging as a result of the Employment Regional Planning for the Porto Metropolitan Area (the first ones opened in Vila do Conde, Valongo and Maia). The Institute for Employment and Professional Training promoted another positive initiative, launching recently a new programme with specific funds to promote telework training to handicapped people and also to support their future integration in the labour market.

Nevertheless, in spite of these incitement policies, which may certainly have a positive impact on telework diffusion, it is consensual that the essential readjustment process that will definitely contribute to achieve this objective is the reorganization of firms, which should change from traditional human resources management models to more modern and efficient ones.

\section{Profile of the Portuguese potential teleworker}


In Portugal, there is no data source currently defined about teleworkers, as periodic population censuses and the more frequent labour force survey do not include any questions connected with this issue. The complete absence of official statistics on the introduction of these new working methods obviously creates great difficulties to the research work and leads to analyses almost entirely based on postal inquiries, some of which with samples without a representative purpose. For this reason, and also because a large-scale implementation of telework has not yet occurred in Portugal, we will focus our attention in an attempt to identify the common attributes of those who are seen as potential teleworkers.

The Association for the Development of Telework (APDT) has been operating since 1997 and has succeeded in attracting the attention of many potential teleworkers, taking advantage of the continuous interest of the media, which has been strategically important in showing to the whole Portuguese society the benefits of telework as a new way of working. This Association allowed us to collect and analyse 994 records, compiled between 1998 and 2002, some of them with information on effective joint-memberships, but the majority of these records is related, however, to preliminary contacts or specific information requests. This empirical work gives us the opportunity to better understand some common characteristics, which is very useful to draw the profile of the Portuguese potential teleworker.

Concerning gender, we perceive a slightly higher female representation $(53,5 \%)$, contrasting for instance with UK figures from the Labour Force Survey (Huws, Jagger, and O'Regan, 1999) where men are clearly over-represented in the teleworking workforce $(68 \%$ compared with $56 \%$ of all workers). However, the analyses of age structure (Chart 1) and educational background (Chart 2) clearly reveal a remarkably higher representation of young and highly qualified people. Almost $70 \%$ was less than 34 years old and had already attended a degree course $(57,2 \%$ of all had taken a degree, masters of $\mathrm{PhD}$ ).

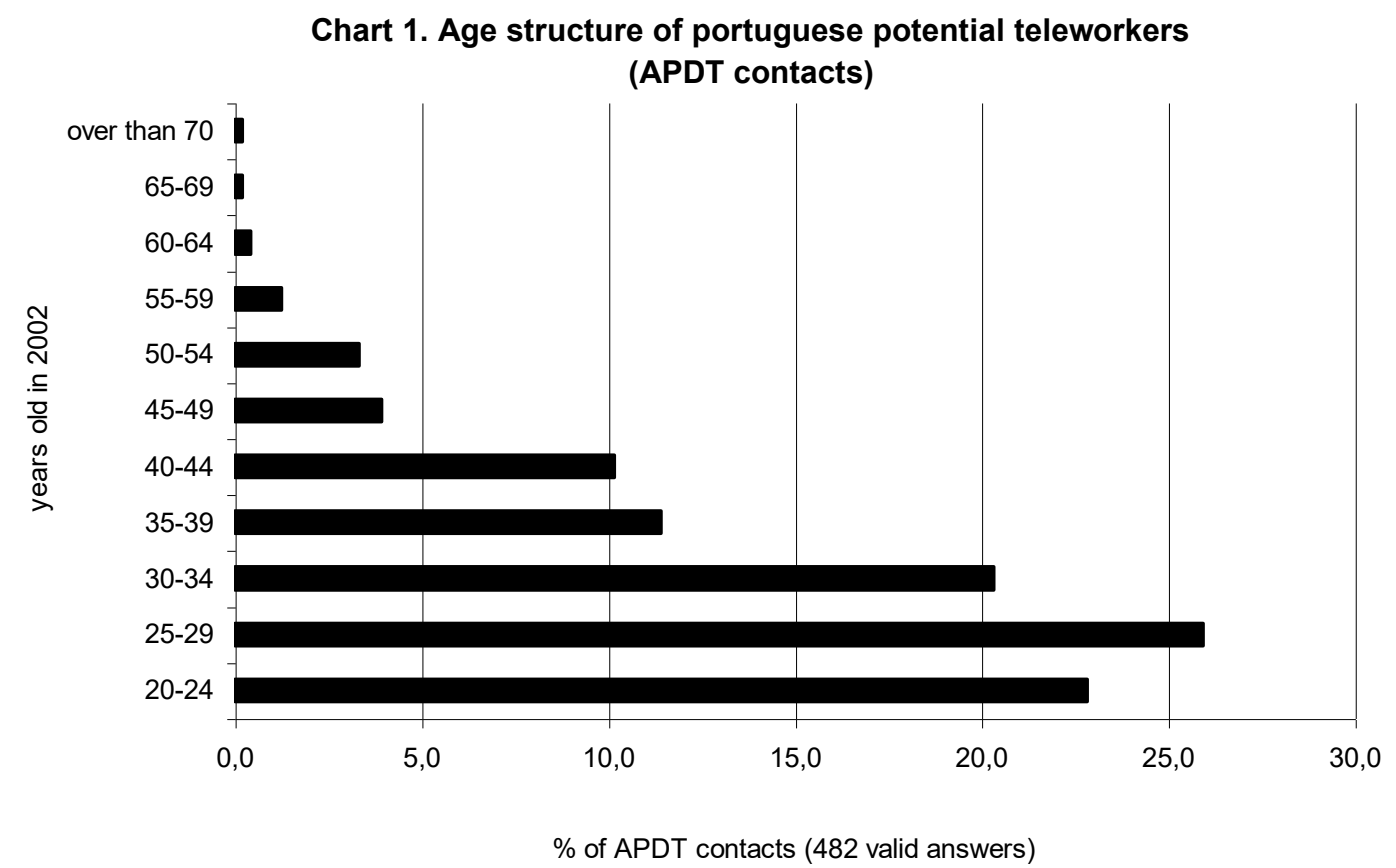

Source: data collected on the APDT - Portuguese Association for the Development of Telework (July, 2002) 


\section{Chart 2. Education background of portuguese potential teleworkers}

(APDT contacts: 507 valid answers)

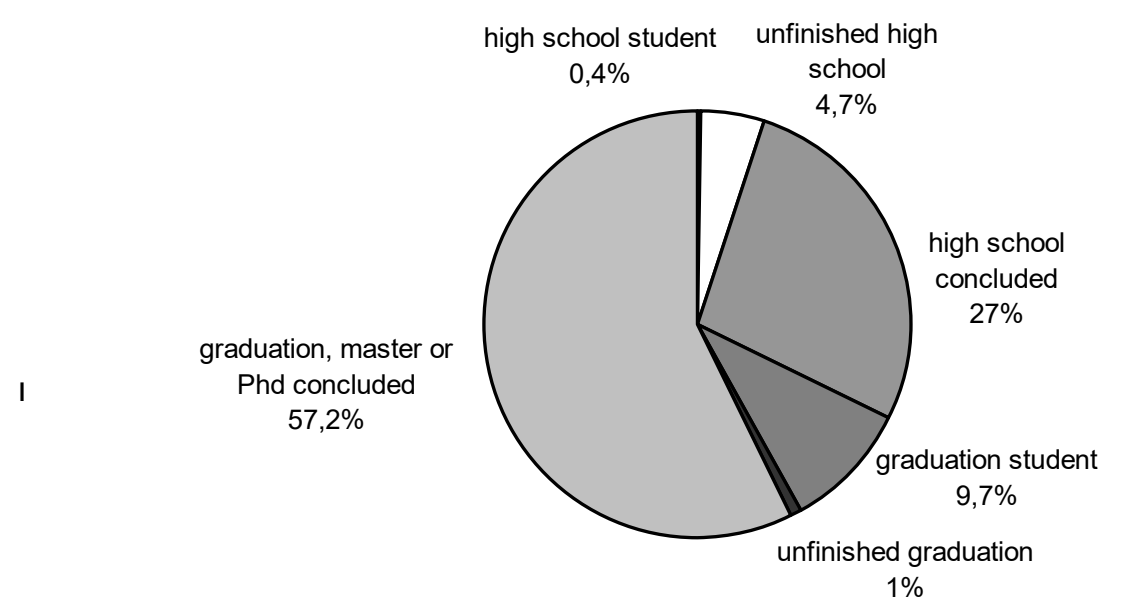

Source: data collected on the APDT - Portuguese Association for the Development of Telework (July, 2002)

The qualified Portuguese young people are definitely the ones more interested in participating in telework activities, probably for belonging to the group that reveals more capabilities in activities more adaptable to telework, as a consequence of the already known ICT illiteracy among other Portuguese groups.

These are surprising figures in comparison to national values regarding qualifications or age profiles. Portugal is a country with very low education standards, since in 2001 only $16 \%$ of the economically active population had a university degree. Portuguese potential teleworkers are also over-represented in the $20-35$ age group (almost $70 \%$ in comparison to $43 \%$ of all active persons), which is a younger profile than the one, for instance, of the average teleworker in the USA, who also has a university degree but is 35 to 44 years old (Hotopp, 2002). Similar findings came from the UK where teleworking is most likely in mid-career (Huws, Jagger, and O'Regan, 1999), in this country $32 \%$ of teleworkers are in the 35 to 44 age bracket (compared with $25 \%$ in the whole workforce) and a further $29 \%$ aged 45 to 54 (compared with $22 \%$ of all UK workers).

Concerning the main professions of potential teleworkers (Table 4), we can conclude that there is a clear correlation with the Portuguese business managers' perception of the functions that are more adaptable to telework, especially those associated with computer expert activities, or others related to word processing and databases fulfil. These results are somewhat similar to the ones obtained in a survey of more than 7000 employers carried out in 18 European Countries. Concerning the functions involved in ework, the conclusions of this international study point out that software development and support is the function most likely to be carried out remotely, by six out of ten European establishments using ework (Huws an O'Regan, 2001).

These results allow us also to conclude that in Portugal, the benefits of telework are not yet fully acknowledged by workers providing consulting activities, although it would be a very useful method for employers to access a wider set of skills, or skills they will only need on specific occasions.

\begin{tabular}{l|l}
\hline Table 4. Main professions of Portuguese potential teleworkers & $\begin{array}{l}\text { (\% of APDT contacts: } 442 \\
\text { valid answers) }\end{array}$ \\
\hline $\begin{array}{l}\text { Computer expert (programmer, database or systems management, software } \\
\text { engineers,...) }\end{array}$ & 24,9 \\
\hline
\end{tabular}


Administrative work, general office, secretary

Teacher/Instructor

Design/graphic arts

Translator

Sales manager and sales assistant

Journalist

Manager/accountant

Consultant

Others

Source: data collected on the APDT-Portuguese Association for the Development of Telework (July, 2002)

For the purpose of understanding the relevance of teachers as the third professional category, we should analyse the main reasons that justify the desire to become a teleworker (Table 5). The more significant reasons are those related to the need of a part-time job to increase the monthly family income, or to unemployment. Portugal is known to have a high level of unemployment among high school teachers, and also a significant number of young teachers with an incomplete working schedule.

\begin{tabular}{l|l}
\hline Table 5. Main reasons to justify the desire to become a teleworker in Portugal & $\begin{array}{l}\text { (\% of APDT contacts: } 77 \\
\text { explicit reasons) }\end{array}$ \\
\hline $\begin{array}{l}\text { Need for a part-time job to increase monthly family income } \\
\text { Being unemployed }\end{array}$ & 32,5 \\
Having some kind of physical disability & 26,0 \\
Avoiding daily commuting and inflexible working hours & 9,1 \\
Housekeeper who wants some kind of remuneration and needs to feel fulfilled & 7,8 \\
and useful & 7,8 \\
Students who want some kind of remuneration & 2,6 \\
Desire to live outside the city & 1,3 \\
Retired person who wants some occupation and extra-remuneration &
\end{tabular}

Source: data collected on the APDT-Portuguese Association for the Development of Telework (July, 2002)

Surprisingly, these kinds of reasons to justify the desire to become a teleworker are not often mentioned in specialized literature. The intention to avoid daily commuting, the working hours inflexibility, the physical disability, the need for a better conciliation between family life and working ambitions: these are all reasons with some relevance in the Portuguese context, but not as much as the significance of telework as an additional possibility to find an occupation and increase small salaries. This happens partly because in Portugal wages are lower and the cost of living is higher than in other European countries.

This particularity also helps us to better understand the age structure and educational background that characterizes the profile of the Portuguese potential teleworker, since there is a worrying and well-known unemployment rate among recently graduated young people.

The findings of this empirical analysis concerning the residence patterns of the APDT contacts show a higher representation of urban residents. There are 308 municipalities in Portugal, and in $69 \%$ of them (213 municipalities) there was not any contact with the APDT, mostly in municipalities without big cities (in terms of population) and with somewhat lower levels of road accessibility (Figure 1). This can indicate that several initiatives are needed, if we want to explore more efficiently the potentialities of telework as an instrument for regional development, by contributing encouragingly to the promotion of new work opportunities in the Portuguese rural areas.

We may conclude that more than $56 \%$ of all APDT contacts live in the Lisbon Metropolitan Area, specifically in four municipalities: Lisbon, Oeiras, Sintra and Cascais (these four municipalities represent $71 \%$ of all APDT contacts of persons living in the 18 municipalities that make the Lisbon Metropolitan Area). In the Porto Metropolitan Area, representing 11\% of all APDT contacts, the three municipalities of Porto, Matosinhos, and Vila Nova de Gaia represent $71 \%$ of all APDT contacts of persons living in the 9 municipalities that make the Porto Metropolitan Area. This spatial pattern may suggest that, in Portugal, the desire to adhere to 
telework may be directly linked to the desire to avoid daily traffic, to and from work, therefore increasing the workers' living standards. This tendency has been more significant than the relocation of certain functions out of central or branch offices to remote regions.

To conclude, we decided to analyse the most relevant types of information requests made to APDT (Table 6).

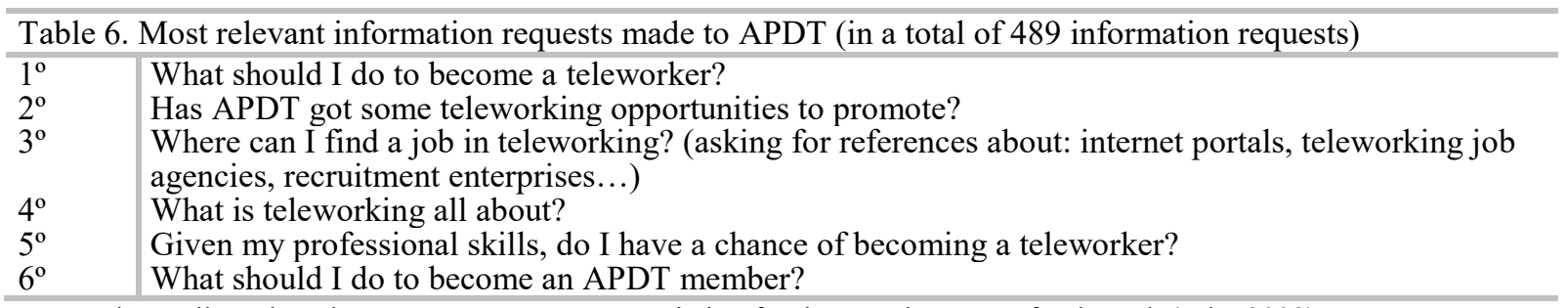

Source: data collected on the APDT-Portuguese Association for the Development of Telework (July, 2002)

According to the hierarchy obtained, it is clear the need to promote actions to diffuse more detailed information about all aspects concerned with this new form of work organization. Analysing these information requests we can also conclude that those who contacted APDT show a strong interest in becoming self-employed teleworkers. This intention reinforces our belief that telework is seen in Portugal as a potential strategy to overtake unemployment problems. For these individuals, the main difficulty is to find an intermediate service (internet portal, teleworking job agency or recruitment enterprise), where their professional skills could be confronted with real teleworking opportunities.

\section{Conclusion}

Although there is a good deal of informal telework taking place, as a result of a gradually increasing use of ICTs among households and companies, the formal adoption of telework as a new working method in Portugal has been somewhat slow in comparison with other European countries (Bates and Huws, 2002). As we have demonstrated, this scenario is a result of a wide range of factors, which can potentially affect the development of teleworking arrangements within the Portuguese context.

A significant spread of telework in Portugal will only be possible if companies and public administration change their organizational procedures, from traditional management (by controlling the performance of workers in a system based on hours of work rather than on results obtained) into more modern and efficient ones. Nevertheless, it is important to say that in Portugal, a reticent attitude towards telework is common not only among managers but also among those employees who work in companies that are likely to implement telework arrangements (fear of isolation and also of a distant attitude from the employers).

Another relevant barrier to the straightforward development of formal telework in Portugal is the lack of awareness showed by central government in recent years. However, this perception seems to be changing, which is proven by some of the policies presented by the current government, namely some significant adjustments promoted in order to fight the rigidity of a labour legislation designed for the well defined and routine-based jobs of the industrial economy, or the intention to promote a network of local telecenters throughout Portugal, or even a set of specific information and training actions aiming at explaining the advantages of telework for employers and employees, as well as its organizational impacts.

Despite these obstacles, in some cases the reasons and stimuli that justify telework adoption in Portugal should be carefully analysed. Some studies draw our attention to the possibility of 
telework being used as a way to spin-off some back-office tasks, through the implementation of service provider systems, which can be seen as a way to weaken work contracts.

Finally, and as regards the profile of potential teleworkers who have contacted the APDT since 1998, the empirical analysis conducted in this paper allows us to say that the individuals showing more interest in adhering to telework in Portugal are qualified young people, generally living in the centre of the two metropolitan areas. Especially computer experts, administrative workers and other professionals that deal with functions more adjustable to telework, but also those who need a part-time job to increase monthly family income, or unemployed people that see telework as an additional possibility to find a professional occupation.

\section{Acknowledgements}

I thank Eng. Miguel Reynolds Brandão and Dr. Isabel Rodrigues for the excellent working conditions during the large period I have spent filling in my databases at APDT - the main Portuguese Association for the Development of Telework. I also thank all the suggestions made by Prof. Iva Pires, as well as all the participants in the ETHICOMP 2004 conference (Syros, Greece), where I presented a preliminary version of this paper, for the valuable discussions.

\section{References}

Araújo, E. (1998), Para uma problemática do teletrabalho. A difícil arte de mudar, Lisboa: Instituto Superior de Economia da Universidade Técnica de Lisboa.

Bates, P. and Huws, U. (2002), Modelling eWork in Europe: estimates, models and forecasts from the EMERGENCE project, Brighton: The Institute for Employment Studies.

Benhamou, E. et al. (1994), Smart Valley Telecommuting Guide, Smart Valey Inc.

Bertin, I. and Denbigh, A. (1998), The teleworking handbook: new ways of working in the information society, Warwickshire: TCA - Telework, Telecottage and Telecentre Association.

Brandão, M. (2001), PORCIDE. Projecto Original para a Rentabilização de Capacidades Integrando Deficientes na Economia

http://www.aboutthink.com/files/pdf/porcide/Relatorio_PORCIDE.PDF_ (accessed in 11.01.2004).

Casaca, S. (2003), 'Teletrabalho: um primeiro balanço sobre os mitos e os factos', paper presented in the X Encontro Nacional de Sociologia Industrial, das Organizações e do Trabalho, Lisboa: Fundação Calouste Gulbenkian.

Correia, A. (1999), Teletrabalho, na perspectiva de trabalhadores e gestores: estudo de caso na Portugal Telecom, Braga: Escola de Economia e Gestão da Universidade do Minho.

Correia, A. (2003), Notas críticas sobre o Novo Código do Trabalho. O teletrabalho (ou trabalho à distância)

http://www.telecentro.pt/documentacao/artigos_entrevistas/codtrabalho.htm (accessed in 14.01.2004). 
EFILWC (1986), Telework, the views and standpoints of the social partners and the workforce and the potential for decentralised electronic working in the European office, Dublin: European Foundation for the Improvement of Living and Working Conditions.

Fiolhais, R. (1998), Sobre as implicações jurídico-laborais do teletrabalho subordinado em Portugal, Lisboa: Instituto do Emprego e Formação Profissional.

Forseback, L. (1995), 20 seconds to work. Home-based telework, Stockholm: Teldok.

Gomes, C. and Aouad, G. (1999), 'Telework, housing and urban planning', in Proceedings of the Sixth European Assembly on Telework and New Ways of Working - Telework'99, 139-155.

Gray, M., Hodson, N. and Gordon, G. (1993), Teleworking Explained, Chichester: John Wiley \& Sons.

Hardill, I. and Green, A. (2003), 'Remote working - altering the spatial contours of work and home in the new economy', New Technology, Work and Employment, 18, 3, 212-222.

Hotopp, U. (2002), 'Teleworking in the UK', Labour Market Trends, July 2002, 311-318

Huws, U. (1991), 'Telework: projections', Futures - The journal of forecasting, planning and policy, 23, 19-31.

Huws, U., Jagger, N. and O'Reagan, S. (1999), Teleworking and Globalisation, Brighton: The Institute for Employment Studies.

Huws, U. (2001), Statistical Indicators of eWork, Brighton: The Institute for Employment Studies.

Huws, U. and O'Regan, S. (2001), Ework in Europe: the EMERGENCE 18-country employer survey, Brighton, The Institute for Employment Studies.

Korte, W. B. and Gareis, K. (2001), 'e-Work in Europe - Indicators for measuring adaptability of work arrangements', in Report of the 8th European Assembly on new ways to work, 46-65, Helsinki: Finland Ministry of Labour and University of Tampere.

MCT (1997), Livro Verde para a Sociedade da Informação em Portugal, Lisboa: Ministério da Ciência e da Tecnologia.

MCT (2000), Programa Operacional Sociedade da Informação, Lisboa: Ministério da Ciência e da Tecnologia.

Mokhtarian, P. L. (1991), Defining Telecommuting

http://www,engr.ucdavis.edu/ its/tcenters/defin.htm (accessed in 10.10.2001).

Muhlbacher, J. R. (1998), 'Teleworking and business reengineering: lessons learned from operating systems development', in R. Traunmuller and E. Csuhaj-Varju (eds), Telecooperation. Proceedings of the XV IFIP World Computer Congress, 301-318, Vienna: Austrian Computer Society. 
Nilles, J. (1985), Teleworking from home, in T. Forester (ed.), The Information Technology Revolution, Massachusetts: The MIT Press, 202-208.

Nilles, J. (1995), 'Scenarios for the development of telework', in F. Reisen and M. Tacken (eds.), A future of telework. Towards a new urban planning concept?, 27-37, Delft: Delf University of Technology.

Oborne, D. (1992), Psychological aspects of teleworking in rural areas, Luxembourg: European Commission.

Portuguese Government (2003), 'Law nº9/2003', Diário da República I Série A, 197, 27 de Agosto de 2003

UMIC (2003), Uma nova dimensão de oportunidades. Plano de Acção para a Sociedade da Informação, Lisboa: Unidade de Missão Inovação e Conhecimento.

Qvortrup, Lars (1998), 'From teleworking to networking', in P. Jackson, J. Van Der Wielen (eds.), Teleworking: international perspectives, London: Routledge.

Reisen, F. and Tacken, M. (1995), 'Telework: chances and effects', in F. Reisen and M. Tacken (eds.), A future of telework. Towards a new urban planning concept?, 13-24, Delft: Delf University of Technology.

Roldão, A. (2002), Teletrabalho e ordenamento do território: impactos sobre o tráfego e escolhas residenciais. O caso da Área Metropolitana de Lisboa, Lisboa: Instituto Superior de Economia e Gestão da Universidade Técnica de Lisboa.

Santana, S. and Rocha, N. (2001), Teletrabalho: análise de um inquérito a empresas portuguesas http://www.apdt.org/docs/Programa\%20IST\%20\%20avalia\%20\%20do\%20mercado.PDF (accessed in 11.01.2004).

Silva, A.; et al. (1998), O teletrabalho em Portugal, Lisboa: Instituto do Emprego e Formação Profissional do Ministério do Trabalho e da Solidariedade.

Simões, J. (1998), O teletrabalho em Portugal: a situação actual e as perspectivas de desenvolvimento. As implicações na gestão de empresas de serviços, Lisboa: Instituto Superior de Economia e Gestão da Universidade Técnica de Lisboa.

Sousa, M. (1999), Teletrabalho em Portugal. Difusão e condicionantes, Lisboa: FCA - Editora de Informática.

Sullivan, C. (2003), 'What's in a name? Definitions and conceptualisations of teleworking and homeworking', New Technology, Work and Employment, 18, 3, 158-165.

Weijers, T., Meijer, R. and Spoelman, E. (1992), 'Telework remains 'made to measure', Futures - The journal of forecasting, planning and policy, 24, 1048-1055. 